\title{
KECERDASAN EMOSIONAL DAN BERFIKIR LOGIS PENGARUHNYA TERHADAP HASIL BELAJAR EKONOMI
}

\author{
Maemunah $^{1^{*}}$, Herman ${ }^{2}$, Rahmatullah $^{3}$ \\ ${ }^{1}$ Pendidikan Ilmu Sosial, Pascasarjana Universitas Negeri Makassar \\ Email : maymunamoon190@gmail.com \\ ${ }^{2}$ Pendidikan Ilmu Sosial, Universitas Negeri Makassar \\ Email: hermanspdmsi1975@yahoo.co.id \\ ${ }^{3}$ Pendidikan Ekonomi, Universitas Negeri makassar \\ Email:rahmatullah@unm.ac.id \\ *Corresponding author
}

\begin{abstract}
The Research purpose is 1 . How to know the influence of emotional intelegent through study result of student partisipan MAN Wajo and SMAN 5 Wajo. The research type is expost facto research is student parcitipan MAN Wajo and SMAN 5 Wajo in class XI IIS. Sample that used number 122 divided into 60 students participant MAN Wajo and 62 student participant SMAN 5 Wajo. Data collection technique apply with using questionnaire in scale likert shape to know the influence emotional entelegent and logical tehniqque whil study result take from technique report score. Data analysis use descriktive analysis technique. Conditional test ofinfrencial statistic analysis. The result of research show 1. Emotional entelegent is significant influenced economy result of student partisipan of MAN Wajo and SMAN 5 Wajo 2. Logical thinking is significant influenced through economy study result of student psrcitipsn of MAN Wajo and SMAN 5 Wajo. 3. Emotional intelegent and logical thngking is significant influenced together trought economi study result of student participant of MAN Wajo and SMAN 5 Wajo. 4. Double liner analysis result show that as simultant variabel emotion intelegent and logical thingking have is significant influence trought economy study result of students participant MAN Wajo and SMAN 5 Wajo.
\end{abstract}

Keywords: Emotional intellegence, Logical thingking, Learning result

\begin{abstract}
Abstrak. Tujuan penelitian ini adalah Untuk mengetahui bagaimana pengaruh kecerdasan emosional terhadap hasil belajar peserta didik MAN Wajo dan SMAN 5 Wajo. Jenis penelitian ini adalah penelitian ex post facto. Populasi dalam penelitian ini adalah peserta didik MAN Wajo dan SMAN 5 Wajo pada kelas XI IIS. Sampel yang digunaka berjumlah 122 diantaranya 60 peserta didik MAN Wajo dan 62 Peserta didik SMAN 5 Wajo. Tehnik pengumpulan data dilakukan dengan menggunakan angket dalam bentuk sklikert untuk mengetahui pengaruh kecerdasan emosional dan berfikir logis sedangkan hasil belajar diambil dari nilai rapor.Teknik analisis data menggunakan teknik analisis deskriptif, uji prasyarat analisis statistik inferensial. Hasil penelitian menunjukkan (1) Kecerdasan emosional berpengaruh signifikanan terhadap hasil belajar ekonomi peserta didik MAN Wajo dan SMAN 5 Wajo; (2) Berfikir logis pengaruh signifikan terhadap hasil belajar ekonomi peserta didik MAN Wajo dan SMAN 5 Wajo ; (3) Kecerdasan emosional dan berfikir logis berpengaruh signifikan secara bersama-sama terhadap hasil belajar ekonomi peserta didik MAN Wajo dan SMAN 5 Wajo; (4) Hasil analisis linier berganda menunjukkan bahwa secara parsial dan simultan variabel kecerdasan emosional dan berfikir logis memiliki pengaruh signifikan terhadap hasil belajar ekonomi peserta didik MAN Wajo dan SMAN 5 Wajo.
\end{abstract}

Kata Kunci: Kecerdasan Emosional, Berfikir Logis, Hasil Belajar 


\section{PENDAHULUAN}

Pemerintah dalam mengupayakan pengembangan sumber daya manusia, salah satu jalan yang ditempuh adalah dengan menyelenggarakan pendidikan formal mulai dari pendidikan dasar, pendidikan menengah, dan perguruan tinggi. Menurut (Rahmatullah, 2018) (Rahmatullah, 2018). aktifitas atau perilaku ekonomi yang dilakukan manusia merupakan cerminan dari pengetahuan dan pemahaman berekonomi yang telah diperoleh melalui proses pembelajaran, khususnya pembelajaran ekonomi pada lembaga pendidikan formal.

Standar pendidikan yang diberlakukan pada kurikulum, menyebutkan bahwa salah satu bagian satuan pendidikan yakni ekonomi. Karena ekonomi merupakan salah satu pengetahuan yang dapat mengembangkan kajian sains dipelajari disekolah. Tujuan dari pendidikan ekonomi pada jenjang pendidikan menengah adalah menekankan pada penataan nalar dan pembentukan kepribadian (sikap) siswa agar dapat menerapkan atau menggunakan ekonomi dalam kehidupannya.

Namun kemerosotan akhlak dan moral perlu segera mendapat penangan yang serius, baik oleh orang tua, guru, maupun lembaga pendidikan yang ikut bertanggung jawab memberi pendidikan dengan proses dan model pembelajaran yang ditawarkan. anak yang mendapatkan kesempatan untuk berkembang dalam lingkungan yang kaya variasi akan menjadi anak yang tanggap dan selalu siap dengan alternatif lain yang diamati dari lingkungan, sehingga membantu anak untuk mengoptimalkan perkembangan fisik dan mentalnya, serta memenuhi kebutuhan kognisi, afeksi, psikomotorik.

Kecerdasan intelektual (IQ) hanya menyumbang $20 \%$ faktor-faktor yang dapat menentukan kesuksesan, maka yang $80 \%$ diisi oleh kekuatan-kekuatan yang lain. Kekuatan yang dimaksud adalah salah satunya kecerdasan emosional atau Emutional Questient (EQ) yakni kemampuan memotivasi belajar diri sendiri, mengatasi frustasi, mengontrol desakan hati, mengatur suasana hati (mood), berempati serta kemampuan bekerja sama menurut Goleman (2005:44)

Hasil belajar adalah kemampuan yang diperoleh anak setelah melalui kegiatan belajar. Hasil belajar ekonomi yang akan diukur yaitu aspek kognitif segi kognitif tersebut berhubungan erat dengan penalaran. Penalaran merupakan salah satu unsur berfikir logis, berfikir logis adalah suatu bentuk kegiatan akal yang tersusun secara sistematis untuk meyelidiki, merumuskan, dan menerangkan asas-asas yang harus ditaati agar siswa dapat membuat kesimpulan yang tepat, lurus, dan teratur. Menurut Nursuprianah (2011:15).

Berdasarkan hasil observasi awal yang dilakukan terhadap kegiatan belajar mengajar yang berlangsung di MAN Wajo pada mata pe lajaran ekonomi, diperoleh gambaran bahwa hasil belajar ekonomi siswa kelas XI jurusan IIS masih tergolong rendah. Hal ini dapat kita lihat dari nilai ujian semester ganjil pada mata pelajaran ekonomi pada tabel 1 berikut ini:

Tabel 1. Nilai rata-rata ujian semester ekonomi siswa kelas XI jurusan IIS MAN Wajo Tahun Ajaran 2017/2018.

\begin{tabular}{lcccccc}
\hline Kelas & $\begin{array}{c}\text { Jumlah } \\
\text { siswa }\end{array}$ & $\begin{array}{c}\text { Nilai rata- } \\
\text { rata }\end{array}$ & $\begin{array}{c}\text { Siswa yang } \\
\text { tuntas }\end{array}$ & $\begin{array}{c}\text { Siswa tidak } \\
\text { tuntas }\end{array}$ & \multicolumn{2}{c}{ \% persentase } \\
\hline IIS 1 & 23 & 70 & 14 & 9 & Tuntas & Tidak Tuntas \\
IIS 2 & 23 & 65 & 15 & 8 & 71,97 & 39,13 \\
IIS 3 & 26 & 57 & 16 & 10 & 57,21 & 34,78 \\
\hline
\end{tabular}

\section{Sumber: Guru ekonomi kelas XI MAN Wajo, 2018}

Hal ini menandakan siswa belum memiliki kecerdasan emosional yang baik. Hal tersebut dapat diketahui saat berlangsungnya proses belajar mengajar dan kegiatan diluar pembelajaran. Saat pembelajaran yang berlangsung siswa belum mampu mengelola emosinya dengan baik, misalnya kurang mampu memotivasi diri sendiri utuk tetap fokus pada pembelajaran,disaat menemui kesulitan dalam belajar siswa cenderung prustasi untuk tidak mau mencari solusi, kurang percaya diri ketika menghadapi tantangan yang dirasa sulit, sulit mengontrol emosi akibatnya 
sering bertengkar dengan teman. Serta belum menerapkan berfikir logis dalam setiap melakukan kegiatan belajarnya. Ditemukan bahwa siswa pasif dalam proses pembelajaran, hanya mendengarkan dan menyalin materi dari buku, kemudian mengerjakan contoh soal. Kebiasaan yang membuat anak bersikap pasif atau menerima begitu saja apa adanya yang mengakibatkan anak tidak terbiasa untuk berpikir logis.

Akan sangat tepat jika seseorang yang memiliki hasil belajar yang tinggi yang mampu mengungkapkan gagasan baru dalam suatu bidang juga mampu mengolah emosinya dengan baik, bersikap tegas, mudah bergaul, mampu memecahkan masalah, serta dapat berfikir dengan baik dan benar.

Kecerdasan emosional dan berfikir logis sangat penting bagi diri siswa yang menjadi salah satu faktor penting untuk meningkatkan hasil belajar siswa dalam proses belajar mengajar.

Menurut Masher (2011: 11) Kecerdasan emosi Adalah kemampuan untuk mengenali, mengelolah, dan mengontorl emosi agar anak mampu untuk merespon secara positif setiap kondisi yang merangsang munculnya emosi-emosi ini dikemukakan pula oleh Goleman dalam Masher (2011: 12) bahwa kecerdasan emosional meliputi mengidentifikasi dan memberi nama perasaanperasaan, mengungkapkan perusahaan, menilai intensiti atas perasaan, mengelola perasaan, menunda pemuasan, mengendalikan dorongan hati, mengurangi stress, dan mengetahui peerbedaan antara perasaan dan tindakan

Beberapa pendapat para ahli yang dikemukakan sebelumnya, disimpulkan bahwa kecerdasan emosional adalah kemampuan yang dimiliki seseorang untuk mengenali, mengontrol emosi (perasaan) dirinya sendiri dan orang lain serta bagaimana cara mengungkapkannya dengan baik demi mencapai tujuan yang diinginkan

Dikemukakan pula oleh Goleman dalam Sarwono (2009: 136) Adapun orang yang dikatakan mempunyai EQ yang tinggi adalah jika ia memenuhi lima kriteria berikut, yaitu :

1. Mampu mengenali emosinya sendiri

2. Mampu mengendalikan emosinya sesuai dengan situasi dan kondisi

3. Mampu menggunakan emosinya untuk meningkatkan motivasinya sendiri (bukan malah membuat diri putus asa atau bersikap negatif pada orang lain)

4. Mampu mengenali emosi orang lain
5. Mampu berintraksi positif dengan orang lain.

Menurut Nurlelah (2015: 5) Berfikir logis dapat diartikan sebagai kemampuan berfikir peserta didik untuk menarik kesimpulan yang benar menurut aturan logika dan dapat membuktikan bahwa kesimpulan itu benar (Valid) sesuai dengan pengetahuan -pengetahuan sebelumnya yang sudah diketahui.

"Berfikir logis adalah secara khusus diperhatikan dalam logika, suatu jalan pikiran yang tepat dan jitu apabila sesuai dengan patokanpatokan yang logis." Jalan pikiran yang tidak mengindahkan potokan-patokan logica itu tentu berantakan dan sesat dan dari pikiran yang sesat yang akan menimbulkan tindakan yang sesat pula Tiro (2004: 08).

Dengan berfikir logis, kita akan mampu membedakan dan mengkritisi kejadian-kejadian yang terjadi pada kita saat ini apakah kejadiankejadian itu masuk akal dan sesuai dengan ilmu pengetahuan atau tidak. Tidak hanya itu, seorang peserta didik harus mampu berfikir logis sehingga ia mampu mengelolah fenomena-fenomena yang diterima oleh sistem indera hingga dapat memunculkan berbagai pertanyaan yang berkaitan dan menggelitik untuk dicari jawabannya.

Indikator kemampuan penalaran logis dalam penelitian ini merujuk kepada teori Hartono (2013: 202) seperti mengumpulkan fakta, membangun dan menetapkan asumsi, menilai atau menguji asumsi, menetapkan generalisasi, membangun argumentasi yang mendukung, memeriksa atau menguji kebenaran argument, menetapkan kesimpulan.

Dari uraian tersebut kita tahu bahwa dengan berfikir logis, yaitu siswa pasif dalam proses pembelajaran, hanya mendengarkan dan menyalin materi dari buku, kemudian mengerjakan contoh soal. Kegiatan berfikir logis hendaknya diberikan untuk selalu tanggap terhadap permasalahan tersebut. Pembelajaran bermakna yang diharapkan dapat mengembangkan kemampuan berfikir logis dan sikap berfikir logis juga merupakan berfikir secara analitis, yaitu dengan menguji sebuah pernyataan atau bukti dengan standar objektif yang akhirnya memutuskan standar dasar logika.

Hasil belajar merupakan suatu proses dimana seseorang mengalami. Perubahan prilaku karena adanya pengalaman dan proses belajar telah terjadi. Hasil belajar menurut Purwanto,(2013: 54) 
adalah "perubahan perilaku yang terjadi setelah mengikuti proses belajar sesuai dengan tujuan pendidikan".

Hasil belajar adalah sasaran yang diharapkan oleh semua pihak namun hasil belajar harus relevan dengan tujuan pengajaran karena hasil belajar sering digunakan sebagai ukuran untuk mengetahui seberapa jauh orang menguasai bahan/matri yang diajarkan.

\section{METODE PENELITIAN}

Jenis penelitian ini merupakan penelitian ex post facto yang bersifat pengaruh dan bertujuan melihat pengaruh kecerdasan emosional, berfikir logis, terhadap hasil belajar ekonomi tanpa adanya suatu perlakuan yang diterapkan.

Teknik pengumpulan data dalam penelitian ini dikumpulkan melalui teknik kuisioner. Teknik kuisioner merupakan alat yang digunakan dalam mengumpulkan informasi yang berkaitan dengan kecerdasan emsional dan berfikir logis.

Analisis data dilakukan dengan analisis deskriptif yaitu mencari nilai rata-rata dari data kecerdasan emosional dan berfikir logis. Mencari rata-rata menggunakan rumus:

$$
\text { rata }- \text { rata }=\frac{\text { skorperolehan }}{\text { skortotal }} \times 100
$$

\section{HASIL PENELITIAN}

Analisis kecerdasan emosional MAN Wajo dan SMAN 5 Wajo

Tabel 2. Data Hasil Analisis Statistik Deskriptif Kecerdasan Emosional Peserta Didik Pada Mata Pelajaran Ekonomi MAN Wajo

\begin{tabular}{ccccc}
\hline No & Interval & Frekuensi & Persentase & Kategori \\
\hline 1. & $71-72$ & 4 & $6,6 \%$ & Sangat Rendah \\
2. & $73-74$ & 12 & $20,0 \%$ & Rendah \\
3. & $76-78$ & 18 & $30,0 \%$ & Sedang \\
4. & $79-81$ & 16 & $26,7 \%$ & Tinggi \\
5. & $82-83$ & 10 & $16,7 \%$ & Sangat Tinggi \\
\hline & Jumlah & 60 & $100 \%$ & \\
\hline
\end{tabular}

Berdasarkan data pada tabel 2 Dapat dikemukakan bahwa kecerdasan emosional peserta didik berada pada kategori rendah dari hasil tersebut diketahui bahwa indikator yang digunakan untuk mengukur kecerdasan emosional ada pada kategori rendah dengan frekuensi 18 sehingga dapat dikemukakan bahwa peserta didik dalam kategori sedang dalam mengenali emosi diri, sehingga kurang mampu mengendalikan emosi disaat marah, dan dalam mengelola emosi masih mengengeluarkan kata-kata kasar apabila sedang kesal. Peserta didik dalam memotivasi belajar diri sendiri masih kurang, ini disebabkan karena merasa biasa-biasa saja dengan hasil belajar yang rendah. Selain itu peserta didik masih kurang mampu dalam mengenali emosi orang lain dan membina hubungan dengan orang lain.

Tabel 3. Data Hasil Analisis Statistik Deskriptif Kecerdasan Emosional Terhadap Hasil Belajar Peserta Didik Pada Mata Pelajaran Ekonomi SMAN 5 Wajo

\begin{tabular}{ccccc}
\hline No & Interval & Frekuensi & Persentase & Kategori \\
\hline 1. & $73-75$ & 10 & $16,1 \%$ & Sangat Rendah \\
2. & $76-78$ & 15 & $24,2 \%$ & Rendah \\
3. & $79-81$ & 17 & $27,5 \%$ & Sedang \\
4. & $82-84$ & 19 & $30,6 \%$ & Tinggi \\
5. & $85-86$ & 1 & $1,6 \%$ & Sangat Tinggi \\
\hline & Jumlah & 62 & $100 \%$ & \\
\hline
\end{tabular}


Berdasarkan data pada tabel 3 Dapat dikemukan bahwa kecerdasan emosional peserta didik berada pada kategori tinggi dari hasil tersebut diketahui bahwa indikator yang digunakan untuk mengukur kecerdasan emosional ada pada kategori tinggi dengan frekuensi 19 sehingga dapat dikemukakan bahwa peserta didik dalam kategori tinggi dalam mengenali emosi diri, sehingga mampu mengendalikan emosi disaat marah, dan dalam mengelola emosi. Peserta didik mampu memotivasi belajar diri sendiri. Selain itu peserta didik mampu mengenali emosi orang lain dan membina hubungan dengan orang lain.

\section{Analisis Berfikir Logis}

Tabel 4. Data Hasil Analisis Statistik Deskriptif Berfikir Logis peserta didik pada mata pelajaran ekonomi MAN Wajo

\begin{tabular}{ccccc}
\hline No & Interval & Frekuensi & Persentase & Kategori \\
\hline 1. & $70-72$ & 10 & $16,7 \%$ & Sangat Rendah \\
2. & $73-75$ & 8 & $13,3 \%$ & Rendah \\
3. & $76-78$ & 21 & $35,0 \%$ & Sedang \\
4. & $79-82$ & 15 & $25,0 \%$ & Tinggi \\
5. & $83-85$ & 6 & $10,0 \%$ & Sangat Tinggi \\
\hline & Jumlah & 60 & $100 \%$ & \\
\hline
\end{tabular}

Berdasarkan data tabel 4 diatas dapat dilihat bahwa hasil belajar peserta didik MAN Wajo berada pada kategori sedang dengan frekuensi 21 peserta didik. Sehingga dapat dikemukakan bahwa kemampuan peserta didik berada pada kategori sedang. Sehingga peserta didik masih kurang mampu mengelola dan menilai fakta yang ditemukan serta dalam menetapkan generelisasi yang membangun argument masih bingun sehingga untuk menentukan kesimpulan belum mampu secara optimal.

Tabel 5. Data Hasil Analisis Statistik Deskriptif Berfikir Logis peserta didik pada mata pelajaran ekonomi

\begin{tabular}{ccccc} 
& SMAN 5 Wajo & & & \\
\hline No & Interval & Frekuensi & Persentase & Kategori \\
\hline 1. & $62-66$ & 2 & $16,7 \%$ & Sangat Rendah \\
2. & $67-71$ & 14 & $13,3 \%$ & Rendah \\
3. & $72-76$ & 23 & $35,0 \%$ & Sedang \\
4. & $77-81$ & 13 & $25,0 \%$ & Tinggi \\
5. & $82-84$ & 10 & $10,0 \%$ & Sangat Tinggi \\
\hline & Jumlah & 62 & $100 \%$ & \\
\hline
\end{tabular}

Berdasarkan data table 5 dapat dilihat bahwa hasil belajar peserta didik SMAN 5 Wajo berada pada kategori sedang dengan frekuensi 23 peserta didik. Sehingga dapat dikemukakan bahwa kemampuan peserta didik berada pada kategori Analisis Hasil Belajar

Tabel 6. Data Hasil Analisis Statistik Deskriptif Hasil Belajar Peserta Didik Pada Mata Pelajaran Ekonomi MAN Wajo

\begin{tabular}{ccccc}
\multicolumn{2}{c}{ MAN Wajo } & & & \\
\hline No & Interval & Frekuensi & Persentase & Kategori \\
\hline 1. & $70-73$ & 6 & $10,0 \%$ & Baik Sekali \\
2. & $74-77$ & 18 & $30,0 \%$ & Baik \\
3. & $78-81$ & 15 & $25,0 \%$ & Sedang \\
4. & $82-85$ & 26 & $26,7 \%$ & Kurang \\
5. & $86-89$ & 5 & $8,3 \%$ & Kurang Sekali \\
\hline & Jumlah & 60 & $100 \%$ & \\
\hline
\end{tabular}

sedang. Sehingga peserta didik kurang mampu mengumpulkan fakta, mengelola dan menilai fakta yang ditemukan serta dalam menetapkan generelisasi, membangun argument dan menguji kebenaran argument masih kurang mampu. 
Berdasarkan hasil olah data pada tabel 6 menunjukkan bahwa hasil belajar pada peserta didik MAN Wajo berada pada kategori sedang, dilihat dari skor rata-rata 76,97\%. Terdapat hasil belajar peserta didik yang masuk dalam kategori dilihat dari interval 82-85 sebanyak 26 peserta didik dengan presentase $26,7 \%$. Hasil belajar peserta didik yang masuk dalam kategori tinggi dilihat dari interval 70-73 sebanyak 6 peserta didik dengan presentase 10,0 sangat rendah. Selanjutnya yang masuk dalam kategori sedang 15 peserta didik dengan persentase $25,0 \%$, rendah dengan 18 peserta didik dengan persentase $30,0 \%$. Serta sangat tinggi dengan peserta didik sebnayak 5 dan persentase sebesar $8,3 \%$.

Berdasarkan data diatas dapat dilihat bahwa hasil belajar peserta didik MAN Wajo berada pada kategori sedang dengan frekuensi 26 peserta didik. Sehingga dapat dikemukakan bahwa kemampuan peserta didik pada pelajaran ekonomi MAN Wajo berada pada kategori Tinggi.

Tabel 7. Data Hasil Analisis Statistik Deskriptif Hasil Belajar Peserta Didik Pada Mata Pelajaran Ekonomi SMAN 5 Wajo

\begin{tabular}{ccccc}
\hline No & Interval & Frekuensi & Persentase & Kategori \\
\hline 1. & $70-73$ & 6 & $10,0 \%$ & Baik Sekali \\
2. & $74-77$ & 18 & $30,0 \%$ & Baik \\
3. & $78-81$ & 15 & $25,0 \%$ & Sedang \\
4. & $82-85$ & 26 & $26,7 \%$ & Kurang \\
5. & $86-89$ & 5 & $8,3 \%$ & Kurang Sekali \\
\hline & Jumlah & 62 & $100 \%$ & \\
\hline
\end{tabular}

Berdasarkan hasil olah data pada tabel 7 menunjukkan bahwa hasil belajar pada peserta didik SMAN 5 Wajo berada pada kategori sedang, dilihat dari skor rata-rata $78,10 \%$. Terdapat hasil belajar peserta didik yang masuk dalam kategori dilihat dari interval 78-81 sebanyak 23 peserta didik dengan presentase $33,9 \%$. Sedangkan dengan kategori rendah sebanyak 11 peserta didik $(17,1 \%)$, Rendah sebanyak 21 peserta didik $(37,1 \%)$, dan tinggi sebanyak 4 peserta didik dengan persentase $(6,5 \%)$, serta sangat tinggi 3 peserta didik dengan persentase $(4,8 \%)$.

Berdasarkan data diatas dapat dilihat bahwa hasil belajar peserta didik MAN Wajo berada pada kategori sedang dengan frekuensi 23 peserta didik. Sehingga dapat dikemukakan bahwa kemampuan peserta didik pada pelajaran ekonomi SMAN 5 Wajo berada pada kategori sedang.

\section{HASIL DAN PEMBAHASAN}

Sesuai dengan hasil dari penelitian yang diperoleh nilai $F_{\text {hitung }}$ adalah 12,249 MAN Wajo dan 18,510 SMAN 5 Wajo yang lebih besar dari pada $\mathrm{f}_{\text {tabel }}$ yaitu 3,16 MAN Wajo dan 3,15 SMAN 5 Wajo . Taraf signifikan $\mathrm{f}$ adalah 0.000 yang lebih kecil dari taraf signifikan yang digunakan yaitu $(\alpha) 0,05$, dengan demikian maka dapat disimpulkan bahwa kecerdasan emosional dan berfikir logis secara simultan memiliki pengaruh juga signifikan terhadap minat berwirausaan pada peserta didik MAN Wajo dan juga pada peserta didik SMAN 5 Wajo.

Persamaan regresi kecerdasan emosional dan berfikir logis terhadap hasil belajar pada peserta didik MAN Wajo dan SMAN 5 wajo. Berdasarkan tabel 4.22 adalah $\mathrm{Y}=24,626+0,354 \mathrm{X} 1+0,322 \mathrm{X} 2$.

Hal ini berarti bahwa jika kecerdasan emosional dan berfikir logis adalah nol maka hasil belajar pada peserta didik MAN Wajo adalah sebesar 24,626 dan berdasarkan tabel 4.22 adalah $\mathrm{Y}=15,324+0,375 \mathrm{X} 1+0,322 \mathrm{X} 2$. Dan peserta didik SMAN 5 Wajo adalah sebesar 15,324. Pengaruh signifikan kecerdasan emosional terhadap hasil belajar pada peserta didik MAN Wajo dan SMAN 5 Wajo. Nilai $t_{\text {hitung }}$ 2,519 MAN Wajo dan SMAN 5 Wajo nilai $\mathrm{T}$ tabel 2,980. Yang lebih besar dari $t_{\text {tabel }}$ yaitu 2,00 dan taraf signifikan t yang diperoleh adalah 0,015 pada MAN Wajo dan taraf signifikan $t$ yang diperoleh 0,004 pada SMAN 5 Wajo yang lebih kecil dari taraf signifikan yang digunakan ( $\alpha) 0,05$, sehingga berdasarkan kriteria tersebut dapat disimpulkan bahwa kecerdasan emosional memiliki pengaruh yang signifikan terhadap hasil belajar peserta didik MAN Wajo dan SMAN 5 Wajo.

Koefisien regresi sebesar 0,354X1 pada MAN wajo dan SMAN 5 Wajo koefesien regresi sebesar 0,357X1 pada kecerdasan emosional 
Maemunah, Herman, Rahmatullah, Kecerdasan Emosional dan Berfikir Logis ... 72

menunjukkan adanya hubungan positif antara kecerdasan emosional dengan hasil belajar pada peserta didik MAN Wajo dan SMAN 5 Wajo. Jika nilai kecerdasan emosional bertambah satusatuan menyebabkan hasil belajar bertambah sebesar 0,354 pada MAN Wajo dan SMAN 5 Wajo sebesar 0,357 .

Hal ini dikarenakan mengenali emosi dan mengelola emosi dirinya dalam proses pembelajaran berlangsung, mampu memotivasi belajar diri, mengenali emosi orang lain dan membina hubungan yang baik dengan orang lain yang berada pada lingkungan sekitarnya, namun masih dapat ditingkatkan.

Berfikir logis menunjukka adanya signifikan nilai $t_{\text {hitung }} 2,696$ pada MAN Wajo dan 2,557 $\mathrm{p}$ ada SMAN 5 Wajo yang lebih besar dari $t_{\text {tabel }}$ yaitu 2,00 dan taraf signifikan $t$ yang diperoleh adalah 0,009 pada MAN Wajo dan 0,013 pada SMAN 5 Wajo yang lebih kecil dari taraf signifikan yang digunakan $(\alpha) 0,05$ sehingga berdasarkan kriteria tersebut dapat disimpulkan bahwa berfikir logis memiliki pengaruh yang signifikan terhadap hasil belajar pada peserta didik MAN Wajo dan SMAN 5 Wajo.

Koefisien regresi sebesar 0,322X2 pada berfikir logis menunjukkan hubungan positif antara berfikir logis dengan hasil belajar pada peserta didik MAN Wajo dan pada peserta didik SMAN 5 Wajo. Jika nilai berfikir logis bertambah satu-satuan menyebab hasil belajar bertambah sebesar 0,322.

Hal ini dikarenakan dalam pengumpulan fakta dan menetapkan asumsi dalam mengikuti pembelajaran ekonomi seperti kemampuan peserta didik dalam menemukan pemecahan masalah dalam proses pembelajaran. Menilai asumsi kemudian menetapkan generelisasi sehingga membangun argumentasi dan mampu menguji kebenaran argument serta dapat menetapkan kesimpulan agar mampu menganalisis dam memahami dari materi pembelajaran ekonomi.

\section{PEMBAHASAN}

\section{Kecerdasan Emosional Terhadap Hasil Belajar Ekonomi Peserta Didik MAN Wajo dan SMAN 5 Wajo}

Nilai kecerdasan emosional peserta didik MAN Wajo umumnya berada pada rata-rata $77,82 \%$. Dan nilai rata-rata peserta didik SMAN 5 Wajo berada pada 79,60\% yang diperoleh dari hasil analisis deskriptif. Hal ini menunjukkan bahwa rata-rata siswa mampu dalam mengenali emosi diri, mengelola emosi sendiri, mampu memotivasi diri, mampu memahami emosi orang lain serta membina hubungan yang baik dengan orang lain yang berada pada lingkungan sekitarnya, namun masih dapat ditingkatkan. Sebagian siswa yang belum mampu kecerdasan emosional yang tinggi dikarenakan peserta didik masih kurang mampu mengenali emosinya dan mengontrol emosinya sendiri dan peserta didik belum mampu mengendalikan dirinya untuk memotivasi diri untuk belajar serta peserta didik belum mampu untuk mengontrol diri dalam membina hubungan yang baik dilingkungannya.

Sesuai dengan nilai koefesien determinasi (Rs) sebesar 0,480\%, kecerdasan emosional menyumbang $0,480 \%$ bagi nilai hasil belajar ekonomi peserta didik MAN Wajo dan SMAN 5 Wajo sebesar $0,563 \%$, kecerdasan emosional menyumbang $0,563 \%$ bagi nilai hasil belajar ekonomi peserta didik. Ini sesuai dengan pendapa Goleman (2005:44) "IQ menyumbang kira-kira $20 \%$ bagi faktor-faktor yang menentukan sukses dalam hidup maka $80 \%$ di isi oleh kekuatan-kekuatan lain". Apabila teori Goleman tersebut di interpretasikan dalam penelitian ini dapat dijelaskan bahwa kecerdasan emosional mempengaruhi nilai hasil belajar ekonomi peserta didik MAN Wajo sebesar 0,480\% dan SMAN 5 Wajo 0,563\%. Selebihnya nilai hasil belajar dipengaruhi oleh kecerdasan intelektual dan faktor-faktor lain.

\section{Berfikir Logis Terhadap Hasil Belajar Ekonomi Peserta Didik MAN Wajo dam SMAN 5 Wajo}

Hasil nilai berfikir logis peserta didik MAN Wajo umumnya berada pada rata-rata $77,12 \%$. Dan nilai rata-rata peserta didik SMAN 5 Wajo berada pada 78,63\% yang diperoleh dari hasil analisis deskriptif. Hal ini menunjukkan bahwa rata-rata peserta didik mampu dalam mengumpulkan fakta serta membangun asumsi serta menilai asumsi yang diperoleh. Dan sudah mampu menetapkan generalisasi dan menguji sampai pada penentuan kesimpulan suatu masalah dalam pembelajaran.

Sesuai dengan nilai koefesien determinasi (Rs) sebesar $0,474 \%$, berfikir logis menyumbang $0,474 \%$ bagi nilai hasil belajar ekonomi peserta didik MAN Wajo dan SMAN 5 Wajo sebesar $0,541 \%$, berfikir logis menyumbang $0,541 \%$ bagi nilai hasil belajar ekonomi peserta didik. Berfikir logis mempengaruhi nilai hasil belajar ekonomi peserta didik MAN Wajo sebesar $0,474 \%$ dan 
SMAN 5 Wajo 0,541\%. Selebihnya nilai hasil belajar dipengaruhi faktor-faktor lain

\section{Kecerdasan Emosional dan Berfikir Logis Secara Bersama-sama Terhadap Hasil Belajar Ekonomi Peserta Didik MAN Wajo dan SMAN 5 Wajo.}

Pernyataan hipotesis ketiga yang menyatakan terdapat pengaruh kecerdasan emosional dan berfikir logis terhadap hasil belajar MAN Wajo dan SMAN 5 Wajo dapat dilihat melalui hasil analisis F-hitung lebih besar dari F-tabel maka $\mathrm{H}_{0}$ ditolak dan $\mathrm{H}_{1}$ diterima. Artinya terdapat pengaruh kecerdasan emosional dan berfikir logis terhadap hasil belajar peserta didik MAN Wajo dan SMAN 5 Wajo. Berdasarkan persamaan regresi linearnya di MAN Wajo yaitu $(\mathrm{Y}=0,548+0,301+0,276)$ persamaan regresi linear di SMAN 5 Wajo $(\mathrm{Y}=$ $0,452+0,204+0,177)$.

Berdasarkan hasil persamaan regresi linear kecerdasan emosional dan berfikir logis peserta didik MAN Wajo dan SMAN 5 Wajo terhadap hasil belajar ekonomi memberikan informasi bahwa jika kecerdasan emosional dan berfikir logis peserta didik meningkat maka nilai hasil belajar ekonomi peserta didik tersebut akan meningkat sebesar $54,8 \%$ pada peserta didik MAN WAjo dan pada SMAN 5 Wajo sebesar 45,2\%. Artinya setiap satu kali kenaikan hasil belajar baik pada MAN Wajo maupun di SMAN 5 Wajo akan bertambah sebesar pada persentase nilai (R) masing-masing sekolah. Serta diperoleh peserta didik yang tidak memiliki kecerdasan emosional dan berfikir logis hanya bisa mencapai nilai hasil belajar ekonomi maksimal sebesar koefesien konstanta.

\section{SIMPULAN DAN SARAN Simpulan}

Kecerdasan emosional berpengaruh terhadap hasil belajar peserta didik MAN Wajo dan SMAN 5 Wajo dapat dilihat dari beberapa indikator yang sudah sesuai dengan kondisi responden yaitu mengenali emosi diri, mengelola emosi, memotivasi belajar diri sendiri, mengenali emosi orang lain, dan membina hubungan.

\section{Saran}

Berdasarkan dari hasil penelitian yang telah dilakukan maka peneliti memberikan saran kepada pihak-pihak yang terkait sebagai berikut: Hasil penelitian ini menunjukkan veriabel kecerdasan emosional dan berfikir logis, baik secara sendiri-sendiri maupun secara bersamasama memberikan pengaruh terhadap hasil belajar ekonomi. Maka disarankan agar variabelvariabel tersebut mendapatkan perhatian serius dari guru ekonomi MAN Wajo dan SMAN 5 Wajo dalam rangka meningkatkan hasil belajar peserta didik pada khususnya dan mutu pendidikan pada umumnya. Bagi peneliti selanjutnya hasil penelitian ini dapat dijadikan pedoman dan hendaknya menambah variabel lain sebagai variabel yang ikut mempengaruhi hasil belajar dan menggunakan objek penelitian yang berbeda sehingga menghasilkan penelitian lebih komprehensif.

\section{DAFTAR PUSTAKA}

Emzir . 2017. Metodologi Penelitian Pendidikan: Kuantitatif Dan Kualitataif. Depok, Indonesia: PT Bajagrafindo Persada.

Hamsah, B. Uno. 2013. Teori Motivasi Belajar dan Pengukurannya Analisis di Bidang Pendidikan. Jakarta: Bumi Aksara.

Muhibin, Syah. 2012. Psikologi Belajar dan Mengajar. Bandung: Sinar Baru Algensindo

Nana, Sudjana. 2012. Penilaian Hasil Proses Belajar Mengajar (cetakan 17). Bandung: Remaja Rosdakarya

Nuralam. 2008. Konsep dan penerapan metodologi penelitian ilmu keperawatan pedoman skripsi. Jakarta: Salemba medika.

Omar, Hamalik. 2012. Psikologi Belajar dan Mengajar. Bandung: Sinar Baru Algensindo.

Purwanto. 2013. Evaluasi Hasil Belajar. Yogyakarta: Pustaka Pelajar.

Rahmatullah, R. (2018). Pembelajaran Ekonomi Berjatidiri Bangsa. JEKPEND: Jurnal Ekonomi Dan Pendidikan, 1(1), 10-16. https://doi.org/10.26858/jekpend.v1i1.505 5

Sugiyono. 2016. Metode Penelitian Kombinasi (Mixed Methods). Jakarta: Alfabeta,

Sarwono, Sarlito. 2009. Pengantar Psikologi Umum. Jakarta: PT Raja Grafindo Persada.

Slameto. 2010. Belajar dan Faktor-Faktor yang Mempengaruhinya (edisi 5). Jakarta: Rineka Cipta,

Tiro, Muhammad Arif. 2004. Bagaimana aku berfikir Makassar. Makassar: Andira Publisher.

Wahab, Rohmalina. 2015. Psikologi Belajar. Jakarta: PT Raja Grafindo Persada. 